\section{COVID-19 Pandemic, National Response Strategies and Marketing Innovations}

\author{
Amy Wenxuan Ding ${ }^{1}$ and Shibo $\mathrm{Li}^{2 *}$ \\ ${ }^{1}$ EMLYON Business School, 23 avenue Guy de Collongue, Ecully Cedex \\ 69134, France
}

${ }^{2}$ Kelley School of Business, Indiana University, 1309 E 10th Street, Bloomington, IN 47405, USA

\begin{abstract}
We provide a short review on our publication-Ding and Li (2020, Business Horizons). We find that during the COVID-19 pandemic, different nations have adopted three different response strategies to contain the new coronavirus: strict control with unlimited resources, relentless contribution with limited resources, and rough rationality with limited resources. We discuss what marketing innovation strategies that enterprises may adopt to survive and grow their businesses during and after the pandemic. This study provides important strategic implications for national policymakers and enterprises on the use of response strategies and marketing innovation strategies in both short and long run.
\end{abstract}

Keywords: COVID-19; Pandemic; Enterprises; Marketing innovation

\section{Introduction}

With the worldwide spread of COVID-19, the World Health Organization (WHO) declared on March 11, 2020, that the coronavirus outbreak was a pandemic and called for countries to take urgent and aggressive actions in response [1]. As of December 22,2020 , the total number of confirmed cases in the world was $77,556,703$, with 1,706,513 deaths, and the number is still rising [2]. National policymakers and enterprises are interested in what response strategies different nations adopt, how effective they are, and how to use marketing innovation as a strategic tool for enterprises to survive

*Corresponding author: Shibo Li, John R. Gibbs Professor of Marketing, Kelley School of Business, Indiana University, 1309 E 10th Street, Bloomington, IN 47405, USA, Tel: 812-8559015; E-mail: shili@indiana.edu

Citation: Ding AW, Li S (2020) COVID-19 Pandemic, National Response Strategies and Marketing Innovations. J Clin Immunol Immunother 6: 053.

Received: December 24, 2020; Accepted: December 28, 2020; Published: December 31, 2020

Copyright: (c) 2020 Ding AW, et al. This is an open-access article distributed under the terms of the Creative Commons Attribution License, which permits unrestricted use, distribution, and reproduction in any medium, provided the original author and source are credited. and grow during and after the pandemic. We address these questions in the publication-Ding and Li (2020, Business Horizons) [3] and provide a short review on it in this article.

\section{Three National Response Strategies}

According to the epistemology of each country for cutting or delaying virus transmission [4,5], we classify national response strategies to the pandemic into three categories with four approaches used in different periods in different countries. The first response strategy is strict control with unlimited resources. Specifically, this strategy focuses on rallying the country's human, material, financial and medical resources to implement a joint prevention and control mechanism to completely block the epidemic situation and cut off the virus transmission channels. Treatment methods include the adoption of mandatory quarantine for all confirmed and suspected patients at various types of hospitals and medically centralized isolation points, the self-isolation at home of all people in a country or state, the full suspension of work and school, community lockdown, and required daily reports on health and out-of-home activities for everyone. For each individual, it is important to implement epidemiological tracking and not to go out without wearing a mask. For example, China has adopted this response strategy.

The second response strategy is relentless contribution with limited resources. Specifically, this strategy does not enforce mandatory isolation or containment. Instead, based on the epidemiological principle of a low COVID-19 mortality rate in the whole society, this strategy allows humans to generate immunity through infection with the virus. As a result, this approach reduces the virus's infectivity to slow the spread of the virus and lowers the peak of the epidemic. Therefore, the patients who die make a life contribution to the production of antibodies throughout society. Two approaches implement this response strategy. a. The herd immunity approach. This approach targets a population infection rate of approximately $60-70 \%$ to develop self-immunization and form a collective shield after infection, thereby limiting the continued spread of the virus and ultimately protecting the entire society. This approach is not an individual-level control strategy. Therefore, there is no strict restriction on travel and community activities. Countries such as the United Kingdom, Sweden and Germany have adopted this approach [6]. b. The herd immunity approach with limited social restrictions. On the one hand, this method is adopted with the expectation that the public will develop self-immunity from COVID-19. On the other hand, the government could be authorized by legislation to implement national emergency regulations and mobilize federal and private resources to urge all hands on deck to protect the health and safety of the public. Therefore, limited restrictions are imposed on the country's transportation to and from key epidemic areas. Countries such as the U.S.A., Italy, France, Spain, and Japan have used this method.

The third response strategy is rough rationality with limited resources. Specifically, this strategy requires closing national borders, severing contact with affected countries and preventing the importation 
of the virus internationally. Within the country, the approach is limited to the lockdown of infected cities and towns without implementing individual-level quarantines or controls. Countries or regions that have adopted this strategy include North Korea, Singapore, South Korea, Taiwan, Macao of China, Russia and Israel.

\section{Marketing Innovation during and after the Pandemic}

While severe crises and catastrophes such as this pandemic are awful, they almost inevitably result in innovations that benefit humanity. In the short term, enterprises may face a number of serious problems, including cash flow shortages, the shutdown of facilities and the disruption of the supply chain. Therefore, it is critical for enterprises to adopt a number of marketing innovation tactics for business survival. In the long run, the crisis could become an opportunity for marketing innovation and business transformation, which will lead to growth and sustainable competitive advantage. As a result, we propose a number of tactics and strategies for enterprises to grow their business and establish sustainable competitive advantages.

First, in the short term, business survival through the pandemic will be the top priority. To ensure survival, an enterprise can adopt a number of quick tactics given the three different national response strategies in its country. There are different innovation tactics to address cash flow shortages, the shutdown of facilities and the disruption of the supply chain. To solve the problem of cash flow shortages, an enterprise can adopt innovative marketing tactics to expand revenue sources and cut costs simultaneously. In terms of revenue expansion, an enterprise can attempt to apply for external funding such as government subsidies, tax cuts, loans, venture capital investments, and outside grants. In addition, the enterprise could engage in rapid marketing innovation internally to explore more revenue sources from its current and new customers. For example, because many consumers are working from home, an enterprise can quickly implement online marketing innovations and establish and expand the online business team to transition their offline businesses online. Examples of such online marketing innovations include using Chatbots and A.I., connecting customers directly using private messaging apps, providing personalized offers and interactive contents to customers, and adopting digital and social media to form authentic relationships with customers and other stakeholders.

Another tactic that an enterprise can use is to undertake marketing innovations, including embracing a customer-centric marketing mindset and engaging in proactive customer relationship management [7]. During the pandemic, many customers naturally run into financial, personal and social difficulties. As a result, they may have a high expectation of the customer services and social responsibilities of firms. More than ever before, customers may attribute product or service issues to the firm, resulting in low customer satisfaction and a high customer attrition rate. Therefore, it is critical for enterprises to proactively adopt a customer-centric mindset by tracking and learning about each customer's needs and preferences over time and making optimal marketing decisions accordingly. Such marketing innovations could effectively bring in new customers and increase revenues from current customers. Enterprises in a country adopting national response strategies II and III, where their production facilities are not completely shut down, can adopt rapid product innovation tactics, including switching to produce face masks, medical protective gear, or other medical equipment if their capabilities allow. They can also try to advance selling of their products and services during the crisis. Finally, the enterprise can implement cost-cutting measures to reduce nonessential production and operation costs. During the crisis, firms should have a people-first mindset and treat their employees, partners and customers fairly.

Facility shutdowns are more severe for enterprises in a country adopting the national response strategy I because an enterprise's factories and offices are usually required to be shut down completely during the pandemic, and reopening depends on the development of the crisis. In countries using national response strategies II or III, an enterprise's factories and offices may still be open for business. Such different requirements in countries with different response strategies may call for different production and operation approaches. Specifically, in the case of a complete shutdown of facilities, the enterprise should move all their business online during the crisis if possible. A company can implement innovative online operations, customer support, product offerings, and internal team collaborations with employees working from home or other safe locations. Enterprises with partial or no shutdowns can also adopt flexible and innovative production and operation schedules, including simultaneous online and offline operation of businesses.

In terms of disruption of the supply chain, no matter which country the enterprise is in, it can attempt within-chain collaborations and innovations. Specifically, within the supply chain, it is important for all channel members to work together and help each other survive the pandemic. For example, a restaurant can close its dine-in business but work closely with online food delivery websites to obtain new contracts and expand its delivery and take-out services.

Second, regarding long-term strategies, this pandemic can serve as an opportunity for a variety of business models, marketing and strategic innovations and business acquisition. In business model innovation, a good long-term strategy is to enable the digitization of the business. For digital and informational products and services, this goal is easy to achieve with the help of the Internet and digital technology. However, for the production of physical material products, digitization is challenging; it requires new artificial intelligence algorithm design and breakthroughs in industrial software. When using mobile robots instead of workers to operate production equipment, they must be able to organize production, logistics, and distribution according to intelligent software. The algorithm design of industrial software should also enable mobile robots to complete planting, breeding and industrial production on time under the remote command of humans. In addition, the pandemic has also revealed that in the future, enterprises' production and business models can adopt a flexible way of combining "peace time-war time" to cope with complex and changing markets. The production technology of an enterprise in ordinary times consists of conventional production. When a crisis occurs, the company's own production technology should be able to quickly turn into a defensive force to maintain the company's continuous production instead of blindly looking for new business opportunities.

Regarding marketing and strategic innovations, enterprises should take a long-term and forward-looking view of business growth. Specifically, companies can embrace the aforementioned customercentric marketing mindset by proactively learning and tracking each customer's needs and preferences over time. During this process, with 
the help of various technologies (e.g., big data, artificial intelligence, machine learning, cloud computing, Internet and information technologies), the enterprise can develop and maintain a win-win relationship with its customers, partners and other stakeholders in the long term. This could also result in new business culture innovation such that a new and financially healthy "customer centric" and "people first" business culture will be put in place. Last, the pandemic could also be a good opportunity for business acquisitions and mergers if it fits the enterprise's strategic goals and if there is sufficient financial support. In summary, a crisis such as the COVID-19 pandemic could become a good opportunity for an enterprise's business survival in the short term, as well as its long-term growth.

\section{References}

1. https://www.who.int/director-general/speeches/detail/who-directorgeneral-s-opening-remarks-at-the-media-briefing-on-covid-19---11march-2020
2. Johns Hopkins University (2020) COVID-19 Dashboard by the Center for Systems Science and Engineering (CSSE) at Johns Hopkins University.

3. Ding AW, Li S (2020) National response strategies and marketing innovations during the COVID-19 pandemic. Business Horizons.

4. Wright RE (2020) The epistemology of Covid-19. "April 11" American Institute for Economic Research.

5. Xiang Z (2020) Covid-19: On the epistemic condition.

6. Campbell D, Proctor K, Elliott L, Carroll L (2020) Coronavirus: As many as 10,000 in Britain may already have it, says PM. The Guardian.

7. Sun B, Li S, Zhou C (2006) "Adaptive" Learning and "Proactive" Customer Relationship Management. Journal of Interactive Marketing 20: 82-96. 


\section{Hif}

Advances In Industrial Biotechnology | ISSN: 2639-5665

Advances In Microbiology Research | ISSN: 2689-694X

Archives Of Surgery And Surgical Education | ISSN: 2689-3126

Archives Of Urology

Archives Of Zoological Studies | ISSN: 2640-7779

Current Trends Medical And Biological Engineering

International Journal Of Case Reports And Therapeutic Studies | ISSN: 2689-310X

Journal Of Addiction \& Addictive Disorders | ISSN: 2578-7276

Journal Of Agronomy \& Agricultural Science | ISSN: 2689-8292

Journal Of AIDS Clinical Research \& STDs | ISSN: 2572-7370

Journal Of Alcoholism Drug Abuse \& Substance Dependence | ISSN: 2572-9594

Journal Of Allergy Disorders \& Therapy | ISSN: 2470-749X

Journal Of Alternative Complementary \& Integrative Medicine | ISSN: 2470-7562

Journal Of Alzheimers \& Neurodegenerative Diseases | ISSN: 2572-9608

Journal Of Anesthesia \& Clinical Care | ISSN: 2378-8879

Journal Of Angiology \& Vascular Surgery | ISSN: 2572-7397

Journal Of Animal Research \& Veterinary Science | ISSN: 2639-375

Journal Of Aquaculture \& Fisheries | ISSN: 2576-5523

Journal Of Atmospheric \& Earth Sciences | ISSN: 2689-8780

Journal Of Biotech Research \& Biochemistry

Journal Of Brain \& Neuroscience Research

Journal Of Cancer Biology \& Treatment | ISSN: 2470-7546

Journal Of Cardiology Study \& Research | ISSN: 2640-768X

Journal Of Cell Biology \& Cell Metabolism | ISSN: 2381-1943

Journal Of Clinical Dermatology \& Therapy | ISSN: 2378-8771

Journal Of Clinical Immunology \& Immunotherapy | ISSN: 2378-8844

Journal Of Clinical Studies \& Medical Case Reports | ISSN: 2378-880

Journal Of Community Medicine \& Public Health Care | ISSN: 2381-1978

Journal Of Cytology \& Tissue Biology | ISSN: 2378-9107

Journal Of Dairy Research \& Technology | ISSN: 2688-9315

Journal Of Dentistry Oral Health \& Cosmesis | ISSN: 2473-6783

Journal Of Diabetes \& Metabolic Disorders | ISSN: 2381-201X

Journal Of Emergency Medicine Trauma \& Surgical Care | ISSN: 2378-8798

Journal Of Environmental Science Current Research | ISSN: 2643-5020

Journal Of Food Science \& Nutrition | ISSN: 2470-1076

Journal Of Forensic Legal \& Investigative Sciences | ISSN: 2473-733X

Journal Of Gastroenterology \& Hepatology Research | ISSN: 2574-2566
Journal Of Genetics \& Genomic Sciences | ISSN: 2574-2485

Journal Of Gerontology \& Geriatric Medicine | ISSN: 2381-8662

Journal Of Hematology Blood Transfusion \& Disorders | ISSN: 2572-2999

Journal Of Hospice \& Palliative Medical Care

Journal Of Human Endocrinology | ISSN: 2572-9640

Journal Of Infectious \& Non Infectious Diseases | ISSN: 2381-8654

Journal Of Internal Medicine \& Primary Healthcare | ISSN: 2574-2493

Journal Of Light \& Laser Current Trends

Journal Of Medicine Study \& Research | ISSN: 2639-5657

Journal Of Modern Chemical Sciences

Journal Of Nanotechnology Nanomedicine \& Nanobiotechnology | ISSN: 2381-2044

Journal Of Neonatology \& Clinical Pediatrics | ISSN: 2378-878X

Journal Of Nephrology \& Renal Therapy | ISSN: 2473-7313

Journal Of Non Invasive Vascular Investigation | ISSN: 2572-7400

Journal Of Nuclear Medicine Radiology \& Radiation Therapy | ISSN: 2572-7419

Journal Of Obesity \& Weight Loss | ISSN: 2473-7372

Journal Of Ophthalmology \& Clinical Research | ISSN: 2378-8887

Journal Of Orthopedic Research \& Physiotherapy | ISSN: 2381-2052

Journal Of Otolaryngology Head \& Neck Surgery | ISSN: 2573-010X

Journal Of Pathology Clinical \& Medical Research

Journal Of Pharmacology Pharmaceutics \& Pharmacovigilance | ISSN: 2639-5649

Journal Of Physical Medicine Rehabilitation \& Disabilities | ISSN: 2381-8670

Journal Of Plant Science Current Research | ISSN: 2639-3743

Journal Of Practical \& Professional Nursing | ISSN: 2639-568

Journal Of Protein Research \& Bioinformatics

Journal Of Psychiatry Depression \& Anxiety | ISSN: 2573-0150

Journal Of Pulmonary Medicine \& Respiratory Research | ISSN: 2573-0177

Journal Of Reproductive Medicine Gynaecology \& Obstetrics | ISSN: 2574-2574

Journal Of Stem Cells Research Development \& Therapy | ISSN: 2381-2060

Journal Of Surgery Current Trends \& Innovations | ISSN: 2578-7284

Journal Of Toxicology Current Research | ISSN: 2639-3735

Journal Of Translational Science And Research

Journal Of Vaccines Research \& Vaccination | ISSN: 2573-0193

Journal Of Virology \& Antivirals

Sports Medicine And Injury Care Journal | ISSN: 2689-8829

Trends In Anatomy \& Physiology | ISSN: 2640-7752

Submit Your Manuscript: https://www.heraldopenaccess.us/submit-manuscript 